\title{
ASURANSI ANGGOTA TUBUH MANUSIA BERDASARKAN ASAS INDEMNITAS
}

\begin{abstract}
Abid Husairi
Alumni Program Magister Kenotariatan Fakultas Hukum Universitas Lambung Mangkurat. Jl.Brigjend H.Hasan Basri Komplek Banjarmasin 70123 Indonesia

Fax:05114321658+E-mail : abidhusairi.mkn@gmail.com
\end{abstract}

Submitted : 10/10/2017 Reviewed 23/03/2018 Accepted:25/03/2018

\begin{abstract}
Abtract: The aims of this research is to study the legislation on body-part insurance in the law prevailing in Indonesia and to study the sum insured and the amount of the compensation of body-part insurance in relation with the principle of indemnity. This research is normative legal research using library study with three kinds of legal resources, which are primary, secondary and tertiary legal resources. The type of this research is vague norms where the are vague in the existing regulations. The approach of this research is statute approach. The characteristic of the research is descriptive analytical because from this research it is expected that holistic, deep and systematic description on regulation concerning body-part insurance in Indonesia, the determination on the sum insured and the amount of the compensation of bodypart insurance in relation with the principle of indemnity can obtained. From the result of the research, it can be concluded that the positive law in Indonesia especially the statutory regulations concerning insurance does not regulate explicitly on the agreement on body-part insurance, however, currently the insurance agreement for body part has been held by referring and prevailing provisions in Commercial Code (KUHD), Article 1 Act Number 40 of 2014 concerning Insurance. The objects of the agreement are parts of the body by referring to Article 1 Act Number 40 of 2014 concerning Insurance, i.e. one of them is the body which in this sense can be interpreted as the part of the body. With regard to the sum insured and the amount of compensation of body-part insurance if we relate it with the principle of indemnity, then it can not be applied or there is difficulty in enforcing the principle of indemnity.
\end{abstract}

Keywords: Body Parts; Principle of Indemnity; and Insurance

Abstrak: Dewasa ini anggota tubuh manusia ternyata dapat diasuransikan dari risiko kerusakan yang diakibatkan proses penuaan atau kecelakaan dalam kerja. Anggota tubuh manusia seperti wajah, hidung, lidah, pita suara, paha, payudara, 
pantat, atau anggota tubuh manusia lain bagi kalangan artis, atlit, atau pemusik merupakan hal yang perlu dijaga, dirawat, dan dipelihara demi penampilan dalam pertunjukan atau berlaga. Beberapa perusahaan asuransi di Indonesia mulai menawarkan asuransi anggota tubuh manusia ini dengan premi yang termahal. Untuk itu perlu ditelaah keberadaannya asuransi anggota tubuh manusia berdasarkan asas indemnitas dalam peraturan perundang-undangan perasuransian di Indonesia. Demikian pula menelaah nilai uang pertanggungan dan ganti rugi yang diberikan kepada tertanggung dalam asuransi tubuh manusia tersebut. Peraturan perundangundangan perasuransian di Indonesia belum mengatur secara eksplisit aturan perjanjian asuransi bagian tubuh manusia. Keberadaan perjanjian asuransi bagian tubuh manusia ini selain merujuk pada asas kebebasan berkontrak, juga merujuk pada ketentuan Kitab Undang-undang Hukum Dagang dan Undang-Undang Nomor 40 Tahun 2014 tentang Asuransi. Berkenaan dengan nilai uang pertanggungan dan ganti rugi asuransi bagian tubuh manusia jika dikaitkan dengan asas indemnitas, maka hal itu tidak dpaat diterapkan atau ada kesulitan dalam menerapkan asas indemnitas dalam menentukan nilai uang pertanggungan dan ganti ruginya.

Kata Kunci:Bagian Tubuh; Prinsip Ganti Rugi; dan Asuransi

\section{PENDAHULUAN}

Sekarang ini manusia mulai merasakan makin banyaknya risiko yang dihadapi dalam hidupnya, sehingga perlu adanya suatu sistem yang dapat mengalihkan risiko tersebut. Pengalihan risiko tersebut dilakukan melalui suatu perjanjian yang dinamakan dengan perjanjian pertanggungan (perjanjian asuransi). Menurut Pasal 246 Kitab Undang-undang Hukum Dagang (Staatsblad Tahun 1847 Nomor 23, untuk selanjutnya disebut KUHD) pertanggungan atau ausransi itu adalah perjanjian dengan mana penanggung mengikatkan diri kepada tertanggung dengan menerima premi untuk memberikan penggantian kepadanya karena kerugian, kerusakan atau kehilangan keuntungan yang diharapkan yang mungkin dideritanya akibat dari suatu evenement.

Peralihan risiko berarti risiko yang akan dihadapi atau yang menjadi tanggung jawabnya itu diusahakan untuk dialihkan kepada pihak lain yang bersedia menerimanya. Dalam perjanjian peralihan risiko terdapat pihak-pihak atau subjek yang terlibat. Subjek dalam perjanjian asuransi adalah orang atau badan-badan usaha yang terlibat pada perjanjian asuransi sebagai tertanggung; sedangkan perusahaan asuransi sebagai penanggung. Peralihan risiko tidak terjadi begitu saja tanpa adanya kewajiban dari para pihak untuk memperjanjikan hal tersebut terlebih dahulu. Pihak lain yang menerima peralihan risiko tersebut dapat menerima sebagian atau seluruhnya. Apabila terjadi pengalihan risiko itu sebagian, maka yang terjadi adalah pembagian risiko. Untuk mengurangi atau menghilangkan beban risiko tersebut, pihak tertanggung berupaya mencari jalan kalau ada pihak lain yang bersedia mengambil alih beban risiko ancaman bahaya dan dia sanggup membayar kontra prestasi yang disebut premi. ${ }^{1}$

Perjanjian asuransi pada umumnya me-

1 Abdul Kadir Muhammad. 2011. Hukum Asuransi Indonesia. Bandung: Citra Aditya Bakti, hlm. 12. 
muat pokok-pokok yang disetujui oleh kedua belah pihak. Hal tersebut dapat ditemui dalam klausula asuransi yang pada dasarnya menyatakan ketentuan-ketentuan yang disetujui oleh penanggung untuk dilakukan dan kondisi umum dimana tertanggung setuju melaksanakan kegiatan tersebut. Perjanjian asuransi jika dilihat dari sifatnya adalah merupakan perjanjian konsensual, yaitu suatu perjanjian yang sudah terbentuk sejak adanya kata sepakat.

Sifat konsensual dari perjanjian asuransi ini terdapat pada Pasal 257 KUHD yang menentukan bahwa perjanjian pertanggungan diterbitkan seketika setelah ia ditutup; hak- hak dan kewajiban-kewajiban bertimbal-balik dari si penanggung dan si tertanggung mulai berlaku semenjak saat itu, bahkan sebelum polisnya ditandatangani. Berarti, sejak ditutupnya perjanjian asuransi, maka perjanjian asuransi itu sudah terbentuk, bahkan sebelum polis tersebut ditandatangani oleh kedua belah pihak. Pada Pasal 257 KUHD tersebut merupakan sebuah penerobosan terhadap Pasal 255 KUHD yang mensyaratkan bahwa perjanjian asuransi harus dibuat dalam suatu akta yang dinamakan polis. Akan tetapi dengan adanya polis yang dijadikan sebagai syarat mutlak dalam perjanjian asuransi tidak berarti asuransi merupakan perjanjian formal. Hal ini dikarenakan berdasarkan Pasal 257 KUHD yang menyatakan bahwa perjanjian asuransi itu sudah terbentuk sejak adanya kata sepakat.

Dewasa ini, asuransi tidak hanya terbatas pada asuransi benda-benda bergerak maupun tidak bergerak seperti asuransi kendaraan bermotor, asuransi rumah, akan tetapi sudah mulai marak asuransi anggota tubuh manusia. Bagi selebriti dunia, tubuh mereka juga termasuk aset yang harus dilindungi oleh asuransi. Kurang lebih sama seperti mengasuransikan rumah serta mobil Anda. Pada beberapa kasus, nilai asuransi bagian tubuh para selebriti ini bahkan mencapai jutaan dolar. Bagian tubuh yang diasuransikan pun beragam, mulai dari kaki, bokong, bahkan senyum. ${ }^{2}$

Di Indonesia sudah ada juga yang mengasuransikan anggota tubuhnya.Asosiasi Asuransi Umum Indonesia (AAUI) menyatakan beberapa perusahaan asuransi di Indonesia sudah mulai menawarkan asuransi bagian tubuh, seperti payudara, pantat sampai kaki seperti yang sudah menjamur di luar negeri. Sebelumnya, penyanyi sensasional Syahrini sempat menyebutkan bahwa ia mengasuransikan bagian tubuhnya. Bagi pelantun lagu sesuatu itu, asuransi sangat penting, terutama bagian tubuh yang menjadi andalannya. "Buat saya itu penting, karena saya pelaku seni yang kerja setiap hari jadi asuransi itu perlu sekali," lanjutnya. Sayang ia tidak menjelaskan bagian mana saja yang diasuransikan. "Ada beberapa bagian, cuma itu sudah jadi daerah pribadi aku, jadi cukup saya sendiri yang tahu," tandas Syahrini. Artis seksi Julia Perez alias Jupe pun juga melakukan hal yang sama. Ketika ditemui Liputan6.com, Jupe membagikan ceritanya seputar perawatan payudaranya termasuk dalam melindunginya.Jupe rela mengeluarkan uang yang tidak sedikit untuk mengasuransikan payudaranya. Hal itu ia lakukan untuk menjaga keindahan payudara yang selalu dirawatnya. ${ }^{3}$

2 Anonim. 2013. Asuransi Tubuh Ala Selebriti. Diakses melalui http://brighterlife. co.id/2013/09/27/asuransitubuhalaselebriti/\#stha sh.TPD7iYxN.dpuf. (Akses 15 Maret 2016.

3 Ariyanti, Fiki. 2015. Artis Hingga Pesebakbbola RI Asuransikan Tubuhnya. Diaksesmelalui http://askrida.com/ artishinggapesepakbolariasuransikantubuhnya. html\#.Vy9c6CHnE28. [diakses 15 Maret 2016]. 
Berdasarkan pemberitaan tersebut di atas bahwa sudah ada yang telah mengasuransikan anggota tubuh, sedangkan di Indonesia perihal asuransi anggota tubuh belum diatur di dalam peraturan perundang-undangan. Namun dalam hal ini sudah terjadi perjanjian asuransi tersebut, sehingga diperlukan ganti kerugian terhadap pemegang polis yang mengalami kerugian sebagai pihak tertanggung sesuai dengan salah satu asas di dalam asuransi yaitu asas indemnitas.

Indemnitas adalah asas yang dikenal di dalam usaha asuransi. Asas indemnitas adalah suatu bentuk asas penggantian kerugian di mana penanggung diwajibkan untuk mengganti kerusakan yang ditimbulkannya kepada tertanggung (sebagai pihak yang mengalami kerugian dan pihak tertanggung dalam asuransi). Dengan telah dilakukan asas indemnitas atau pembayaran oleh penanggung, maka tertanggung tidak dapat meminta ganti rugi kepada pihak penanggung atau perusahaan asuransi.

Berhubung perjanjian asuransi anggota tubuh manusia yang telah ada di Indonesia, namun belum ada pengaturannya dalam peraturan perundang-undangan, maka perlu dikaji mengenai pengaturan asuransi anggota tubuh dalam sistem hukum yang berlaku di Indonesia dan bagaimana penentuan besarnya uang pertanggungan (sum insured) dan besarnya ganti kerugian asuransi anggota tubuh manusia tersebut apabila dihubungkan dengan asas indemnitas.

\section{METODE}

Penelitian ini menggunakan penelitian hukum normatif berupa penelitian kepustakaan yang menelaah bahan hukum primer dan bahan hukum sekunder. Tipe penelitian yang dipergunakan adalah penelitian kekaburan hukum (vage norm, dimana adanya kekaburan antara peraturan satu dengan peraturan hukum lainnya. Untuk menganalisis masalah, penelitian ini menggunakan pendekatan undang-undang (statute approach). Dari sisi lain, sifat penelitian ini adalah preskriptif analitis guna memperoleh gambaran secara menyeluruh, mendalam dan sistematis mengenai pengaturan asuransi anggota tubuh manusia di Indonesia dan penentuan besarnya uang pertanggungan (sum insured) dan besarnya ganti kerugian asuransi anggota tubuh apabila dihubungkan dengan asas indemnitas.

\section{ANALISIS DAN PEMBAHASAN Ekstensi Asuransi Anggota Tubuh Manu- sia dalam Peraturan Perundang-undangan di Indonesia}

Dasar hukum perjanjian asuransi diatur dalam Pasal 1774 Kitab Undang-undang Hukum Perdata (Staatsblad Tahun 1847 Nomor 23; untuk selanjutnya disebut KUH Perdata) yang berbunyi: Suatu perjanjian untung untungan adalah suatu perbuatan yang hasilnya, mengenai untung ruginya, baik bagi semua pihak, maupun bagi sementara, bergantung kepada suatu kejadian yang belum tertentu. Demikian adalah: perjanjian pertanggungan; bunga cagak hidup; perjudian dan pertaruhan. Menurut Pasal di atas, perjanjian asuransi digolongkan ke dalam perjanjian untung- untungan. Penggolongan perjanjian asuransi sebagai perjanjian untung untungan tidak sesuai dengan sifat perjanjian asuransi yang sesungguhnya.

Pembuat undang-undang memasukkan asuransi sebagai perjanjian untung- untungan, seperti perjudian dan pertaruhan yang diatur dalam Pasal 1774 KUH Perdata tersebut berdasarkan pertimbangan bahwa besarnya kewajiban penanggung digantungkan 
pada peristiwa yang tidak pasti. Kewajiban tersebut baru dapat dipenuhi jika peristiwa yang ditanggung benar benar terjadi. Penggolongan perjanjian asuransi secara umum oleh KUH Perdata sebagai salah satu bentuk perjanjian untung- untungan sebenarnya merupakan satu penerapan yang sama sekali tidak tepat di samping bertentangan dengan prinsip prinsip yang harus dipenuhi dalam perjanjian asuransi itu sendiri. Karakteristik perjanjian untung-untungan adalah berdasarkan kemungkinan yang sangat bersifat spekulatif dengan tujuan utama hanya kepentingan keuangan, sementara perjanjian asuransi pada dasarnya mempunyai tujuan yang lebih pasti, yaitu memperalihkan risiko yang sudah ada yang berkaitan pada kemanfaatan ekonomi tertentu, sehingga tetap berada dalam posisi yang sama. Pasal 1774 KUH Perdata yang menyatakan, bahwa perjanjian asuransi diatur selanjutnya dalam KUHD menjadikan asuransi sebagai perbuatan ekonomi yang sah oleh hukum dan pengakuan sah tersebut telah diatur pula dalam berbagai undang-undang diluar KUHD antara lain Undang-Undang Nomor 2 Tahun 1992 tentang Usaha Perasuransian (Lembaran Negara Republik Indonesia Tahun 1992 Nomor 13, Tambahan Lembaran Negara Republik Indonesia Nomor 3467), kemudian dicabut dan dinyatakan tidak berlaku melalui Undang-Undang Nomor 40 Tahun 2014 tentang Perasuransian (Lembaran Negara Republik Indonesia Tahun 2014 Nomor 337, Tambahan Lembaran Negara Republik Indonesia Nomor 5618; untuk selanjutnya disebut UU No. 40/2014). Dengan demikian ketentuan Pasal 1774 KUH Perdata tidak dapat dijadikan dasar hukum perjanjian asuransi.

Pengaturan asuransi sebagai sebuah perjanijan diatur di bawah KUH Dagang. Berda- sarkan Pasal 1 KUHD, hukum dagang dapat dikatakan merupakan lanjutan dari hukum perdata. Oleh sebab itu, ketentuan yang terdapat dalam KUH Perdata sebagai ketentuan khusus, selama oleh ketentuan yang terakhir itu belum diatur sebaliknya. Secara positif, asuransi dan lembaga asuransi beserta pengaturannya telah berlaku di Indonesia sejak tahun 1848, yaitu sejak KUHD berdasarkan asas kondordansi berlaku di Indonesia.

KUHD merupakan induk berbagai ketentuan ketentuan hukum dagang indonesia. KUHD memuat bab-bab tersendiri mengenai asuransi sebagai sebuah perjanjian yang dibagi dalam dua bagian, yaitu pengaturan yang bersifat umum dan pengaturan yang bersifat khusus. Sebagai aturan induk selain dari ketentuan umum mengenai perikatan yang merupakan asas asas yang dikandung oleh $\mathrm{KUH}$ Perdata, ketentuan ketentuan KUHD akan selalu menjadi dasar suatu perjanjian asuransi apabila tidak diatur secara khusus dalam perjanjian asuransi itu sendiri. ${ }^{4}$

Pengertian asuransi menurut KUHD diatur dalam Pasal 246 KUHD. Menurut Pasal 246 KUHD, yang dimaksud dengan "Asuransi adalah suatu perjanjian, dengan mana seorang penanggung mengikatkan diri kepada seorang tertanggung, dengan menerima suatu kerugian, kerusakan atau kehilangan keuntungan yang diharapkan, yang mungin akan dideritanya karena suatu peristiwa yang tak tertentu". Pengertian asuransi juga disebut dalam Pasal 1 angka 1 UU No. 40/2014 yang menyatakan sebagai berikut:

Asuransi adalah perjanjian antara dua pihak, yaitu perusahaan asuransi dan pemegang polis, yang menjadi dasar bagi penerimaan premi oleh perusahaan asur-

4 Ganie A Junaedy. 2011. Hukum Asuransi Indonesia. Jakarta: Sinar Grafika, hlm. 64. 
ansi sebagai imbalan untuk:

a. memberikan penggantian kepada tertanggung atau pemegang polis karena kerugian, kerusakan, biaya yang timbul, kehilangan keuntungan, atau tanggung jawab hukum kepada pihak ketiga yang mungkin diderita tertanggung atau pemegang polis karena terjadinya suatu peristiwa yang tidak pasti; atau

b. memberikan pembayaran yang didasarkan pada meninggalnya tertanggung atau pembayaran yang didasarkan pada hidupnya tertanggung dengan manfaat yang besarnya telah ditetapkan dan/atau didasarkan pada hasil pengelolaan dana.

Pengertian tersebut menunjukkan bahwa perjanjian asuransi merupakan suatu perikatan timbal balik antara penanggung yang memberikan jaminan dan dengan tertanggung yang memberikan imbalan pembayaran premi asuransi. Pengertian asuransi dalam Pasal 246 KUHD tersebut hanya mengatur penggantian kepada tertanggung atas kerugian, kerusakan atau kehilangan keuntungan yang diharapkan. Dalam asuransi jiwa, yang menjadi objek asuransi adalah jiwa tertanggung atau mereka yang diasuransikan dan manfaat yang diberikan dapat berupa santunan kepada seseorang atau lebih yang ditunjuk sebagai penerima manfaat apabila tertanggung atau yang dipertanggungkan meninggal dunia atau penerimaaan manfaat yang disepakati oleh tertanggung yang selamat sampai akhir masa asuransi.

Selain terdapat pengertian dari asuransi, dalam KUHD juga diatur mengenai penggolongan asuransi. Penggolongan asuransi tersebut yakni pada Pasal 247 KUHD menyebutkan bahwa pertanggungan-pertanggungan itu antara lain dapat mengenai:

a. Bahaya kebakaran;

b. Bahaya yang mengancam hasil-hasil pertanian yang belum panen;

c. Jiwa; satu atau beberapa

d. Bahaya laut dan perbudakan;

e. Bahaya yang sering mengancam pengangkutan di daratan, di sungai-sungai,dan di perairan darat.

Semua penggolongan-penggolongan di atas, pada akhirnya diciutkan kembali pada klasifikasi dua besar yaitu: pertama, asuransi kerugian dan kedua, asuransi sejumlah uang. Kedua asuransi tersebut, menjadi dua golongan besar asuransi, karena dalam perkembangan praktik perasuransian muncul jenis-jenis asuransi baru di luar dari jenis-jenis asuransi yang disebutkan dalam KUHD, yang didasarkan pada kebutuhan masyarakat. Semua jenis asuransi baru tersebut dimasukkan ke dalam salah satu golongan besar, yakni asuransi kerugian atau asuransi sejumlah uang tersebut.

Adapun yang paling penting untuk diperhatikan adalah perjanjian asuransi adalah perjanjian atas dasar uberrimae fidei, utmost goodfaith. Dalam sistem common law, terdapat kewajiban yang luas bagi para pihak untuk melakukan keterbukaan (disclosure). Tetapi untuk tujuan yang lebih umum, sebuah perjanjian di mana satu pihak (penanggung) dengan imbalan tertentu, sepakat untuk menanggung risiko dari suatu peristiwa, kejadian yang waktunya tidak dapat ditentukan, atas hal tersebut pihak yang lain (tertanggung) terancam mempunyai kepentingan dan sepakat dalam hal timbulnya peristiwa, kejadian yang ditanggung, penanggung akan membayar kepada tertanggung sejumlah uang, atau menyediakan manfaat dalam bentuk lain yang memiliki nilai keuangan (tidak 
selalu harus membayar dalam bentuk uang).

Pengaturan asuransi dalam KUHD mengutamakan segi keperdataan yang didasarkan pada perjanjian antara tertanggung dan penanggung. Perjanjian tersebut menimbulkan kewajiban dan hak tertanggung dan penanggung secara timbal balik. Sebagai perjanjian khusus, asuransi dibuat secara tertulis dalam bentuk akta yang disebut polis asuransi.

Dalam merumuskan hak dan kewajiban para pihak dalam polis asuransi harus memperhatikan beberapa asas hukum perasuransi, yaitu:

1. Asas indemnitas adalah satu asas utama dalam perjanjian asuransi, karena merupakan asas yang mendasari mekanisme kerja dan memberi arah tujuan dari perjanjian asuransi itu sendiri. Perjanjian asuransi mempunyai tujuan utama dan spesifik ialah untuk memberi suatu ganti kerugian kepada pihak tertanggung oleh pihak penanggung.

2. Asas kepentingan yang dapat diasuransikan merupakan asas utama kedua dalam perjanjian asuransi. Maksudnya adalah bahwa pihak tertanggung mempunyai keterlibatan sedemikian rupa dengan akibat dari suatu peristiwa yang belum pasti terjadinya dan yang bersangkutan menjadi menderita kerugian.

3. Asas kejujuran yang sempurna dalam perjanjian asuransi, lazim juga dipakai istilah-istilah lain yaitu: iktikad baik yang sebaik-baiknya. Asas kejujuran ini sebenarnya merupakan asas bagi setiap perjanjian, sehingga harus dipenuhi oleh para pihak yang mengadakan perjanjian.

4. Asas subrogasi bagi penanggung mes- kipun tidak mempengaruhi sah atau tidaknya perjanjian asuransi, perlu dibahas, karena merupakan salah satu asas perjanjian asuransi yang selalu ditegakkan pada saat-saat dan keadaan tertentu dalam rangka menerapkan asas pertama perjanjian asuransi ialah dalam rangka tujuan pemberian ganti rugi ialah asas indemnitas. ${ }^{5}$

Selain tunduk pada KUHD mengikuti syarat-syarat khusus yang diatur dalam KUHD, berhubung hal pertanggungan adalah perjanjian khusus, maka diberlakukan pula ketentuan umum syarat sah suatu perjanjian sebagaimana dirumuskan dalam Pasal 1320 KUH Perdata.

Dari bunyi ketentuan Pasal 1 angka 1 UU No. 40/2014 dapat diketahui jenis asuransi itu mencakup 2 (dua) macam, yaitu:

a. Asuransi kerugian (loss insurance), dapat diketahui dari frasa/rumusan, yang menyatakan: "untuk memberikan penggantian kepada tertanggung karena kerugian,kerusakan, atau kehilangan keuntungan yang diharapkan, atau tanggung jawab hukum kepada pihak ketiga yang rnungkin akan diderita oleh terlanggung".

b. Asuransi jumlah (sum insurance), yang meliputi asuransi jiwa dan asuransi sosial, dapat diketahui dari frasa/ rumusan yang menyatakan: "untuk memberikan suatu pembayaran yang didasarkan atas meninggal atau hidupnya seseorang yang dipertanggungkan".

Berdasarkan pengertian asuransi dalam Pasal 1 angka 1 UU No. 40/2014, maka ob-

5 Tuti Rastuti. 2011. Aspek Hukum Perjanjian Asuransi. Yogyakarta: Buku Seru, hlm. 31. 
jek asuransi itu terdiri atas jiwa dan raga, kesehatan manusia, tanggung jawab hukum, benda dan jasa, serta semua kepentingan lainnya yang dapat hilang, rusak, rugi dan/ atau berkurang nilainya. Kalau demikian, anggota tubuh manusia termasuk dalam objek asuransi, sebab anggota tubuh manusia memenuhi unsur raga dan dapat rusak, sebagaimana yang terdapat dalam pengertian dan objek asuransi.

Asuransi anggota tubuh manusia ini termasuk ke dalam asuransi sejumlah uang, yaitu pertanggungan untuk mendapatkan sejulah uang tertentu, terlepas dari kerugian yang diderita terhadap suatu kejadian (biasanya mengenai diri tertanggung atau yang diderita) yang belum tentu kapan akan terjadi. Disebut juga dengan asuransi orang (jiwa, sakit, cacat, dan lain-lain). Ciri-ciri asuransi sejumlah uang, yaitu: pertama, adanya sejumlah uang akan dibayar dan kedua, kemungkinan kerugian yang dapat dinilai dengan uang (biarpun hanya kerugian ekonomis) tidak disyaratkan. Ketentuan mengenai objek asuransi yang diatur dalam ketentuan Pasal 1 angka 1 UU No. 40/2014 tersebut di atas, yaitu salah satunya adalah raga yang dalam hal ini bisa diartikan sebagai anggota tubuh manusia.

Secara garis besar yang dimaksud anggota tubuh dalam hal ini, meliputi: kepala, otak, leher, badan, dan anggota badan. ${ }^{6}$ Sampai saat ini pengaturan mengenai asuransi anggota tubuh lebih lanjut belum diatur dalam peraturan perundang-undangan. Selanjutnya mengenai peraturan pelaksana di bawahnya juga tidak ada yang mengatur mengenai asuransi anggota tubuh manusia, sehingga dapat dikatakan

6 Anonim. 2015. Bagian-bagian Tubuh Manusia Dan Fungsinya. Diakses melalui http://usaha321. net/bagian-bagian-tubuh-manusia-dan-fungsinya. html. [Diakses 20 Maret 2017]. bahwa usaha asuransi anggota tubuh manusia di Indonesia masih belum diatur secara jelas dan tegas. Terlepas dari itu semua, pihak yang melakukan perjanjian asuransi anggota tubuh manusia dapat mengacu kepada ketentuan KUH Perdata dan KUHD, sedangkan mengenai pengertian anggota tubuh manusia itu sendiri dapat melihat kepada ketentuan Pasal 1 UU No. 40/2014 tersebut di atas, yaitu salah satunya adalah raga yang dalam hal ini bisa diartikan sebagai anggota tubuh manusia.

\section{Penentuan Besarnya Uang Pertanggungan (Sum Insured) dan Ganti Kerugian Asur- ansi Anggota Tubuh Manusia Apabila Di- hubungkan dengan Asas Indemnitas}

Perjanjian asuransi anggota tubuh manusia adalah suatu persetujuan dua pihak di mana pihak tertanggung membayar premi sebagai prestasi, yang sebagai gantinya menerima ganti rugi dari penanggung. Pembayaran premi kepada pihak penanggung selama kontrak berjalan merupakan kewajiban dari pihak tertanggung/pemegang polis. Dalam Pasal 268 KUHD dinyatakan, bahwa suatu pertanggungan dapat mengenai segala kepentingan yang dapat dinilaikan dengan uang, dapat diancam oleh sesuatu bahaya, dan tidak dikecualikan oleh undang-undang.

Jadi pada hakikatnya, setiap kepentingan itu dapat diasuransikan/ dipertanggungkan, baik kepentingan yang bersifat kebendaan atau kepentingan yang bersifat hak, sepanjang memenuhi syarat yang diminta oleh Pasal 268 KUHD tersebut diatas, yaitu bahwa kepentingan itu dapat dinilai dengan uang, dapat diancam bahaya dan tidak dikecualikan oleh undang-undang. Meskipun demikian, untuk selanjutnya masih perlu/dapat dipertanyakan lagi, kapankah kepentingan itu harus ada. Dalam hal ini, undang-undang mengatur seb- 
agaimana ketentuan Pasal 250 KUHD.

Selanjutnya untuk menentukan besarnya uang pertanggungan atau ganti kerugian apabila dikaitkan dengan asas indemnitas, maka terlebih dahulu perlu diketahui akan pentingnya asas perseimbangan dalam pertanggungan. Asas indemnitas merupakan asas penting, karena risiko yang diperalihkan kepada penanggung itu diimbangi dengan jumlah premi yang dibayar oleh tertanggung Walaupun dapat diperjanjikan bahwa pembayaran premi mungkin tidak seimbang dengan risiko yang ditanggung oleh penanggung tetapi tidak berarti bahwa asas indemnitas itu diabaikan.

Adapun Pasal-pasal yang memuat asas indemnitas di dalam KUHD antara lain terdapat dalam:

1. Pasal 250 KUHD berbunyi: "Apabila tertanggung tidak mempunyai kepentingan, penanggung tidak diwajibkan membayar ganti kerugian";

2. Pasal 252 KUHD berbunyi: "Apabila benda sudah dipertanggungkan dengan nilai penuh, untuk jangka waktu yang sama dan bahaya yang sama, pertanggungan kedua tidak dibolehkan, dengan ancaman batal";

3. Pasal 253 KUHD berbunyi: "Pertanggungan hanya sah sampai jumlah nilai benda sesungguhnya";

4. Pasal 274 KUHD berbunyi: "Penanggung dapat mengajukan keberatan apabila nilai dianggap terlalu tinggi";

5. Pasal 277 KUHD berbunyi: "Apabila atas suatu benda diadakan beberapa pertanggungan sedangkan pertanggungan pertama dengan nilai penuh, penanggung berikutnya dibebaskan";

6. Pasal 279 KUHD berbunyi: "Tertanggung yang membebaskan penanggung terdahulu, menggantikan kedudukannya untuk jumlah yang sama menurut tertib yang sama";

7. Pasal 284 KUHD berbunyi: "Penanggung yang telah membayar kerugian kepada tertanggung memperoleh haknya terhadap pihak ketiga (subrogasi)".

Berdasarkan ketentuan pasal-pasal tersebut di atas, dapat diketahui betapa pentingnya asas indemnitas itu dalam pertanggungan.Di mana ada kepentingan, di situ ada asas indemnitas. Asas indemnitas juga dapat diartikan adalah suatu prinsip yang mengatur mengenai pemberian ganti kerugian. Indemintas dapat diartikan sebagai suatu mekanisme dengan mana si penanggung memberikan ganti rugi finansial dalam suatu upaya menempatkan si tertanggung pada posisi keuangan yang dimiliki pada saat sesaat sebelum kerugian itu terjadi. Hal ini berarti bahwa penanggung akan memberikan ganti rugi sesuai dengan kerugian yang benar-benar diderita tertanggung, tanpa ditambah atau dipengaruhi unsurunsur mencari keuntungan atau profit. $^{7}$

Dalam kontrak asuransi, indemnity dapat diartikan sebagai kompensasi finansial yang pasti yang cukup menempatkan tertanggung dalam posisi keuangan tertanggung setelah kerugian sebagaimana yang dialami sebelum peristiwa terjadi. Adapun bentuk ganti rugi yang dicakup dalam prinsip indemnitas ini bukan hanya berupa sejumlah uang tunai, melainkan juga perbaikan untuk mengembalikan suatu properti/kendaraan seperti keadaan semula serta mengganti kerugian tersebut dengan yang baru dan sama persis. Hal terpenting yang harus dipahami dalam diter-

7 Afrianto Budi. 2012. Prinsip Indemnity, diakses melalui http://www.akademiasuransi.org/2012/09/ prinsip-indemnity.html. [Diakses 6 Desember 2016]. 
apkannya prinsip atau asas indemnitas ini adalah bahwa ganti rugi atau pertanggungan yang diberikan sesuai dan setara dengan besar dan jumlahnya kerugian pihak bersangkutan tersebut yang sesungguhnya.

Di Indonesia pada Pasal 246 KUHD secara jelas bahwa asuransi merupakan suatu perjanjian ganti rugi atau perjanjian indemnitas (contract of indemnity), artinya penanggung berjanji akan membayar ganti rugi seimbang sesuai kerugian yang diderita oleh tertanggung, apabila objek telah dipertanggungkan dengan nilai penuh. Dalam KUHD, terdapat ketentuan yang mencerminkan dipertahankan prinsip ganti rugi diantara pada Pasal 252, 253, dan 284 KUHD. Disebutkan dalam Pasal 252 yang menyatakan:

"Kecuali dalam hal-hal yang disebutkan dalam ketentuan undang-undang, maka tidak bolehlah diadakan suatu asuransi kedua, untuk jangka waktu yang sudah diasuransikan untuk harganya penuh, dan demikian itu atas ancaman batalnya asuransi kedua tersebut Besarnya kerugian dihitung berdasarkan nilai pada sesaat sebelum terjadi peristiwa kerugian.

Faktor-faktor yang dapat memperbesar indemnitas terdapat 4 (empat) bentuk modifikasi prinsip indemnity, yaitu: ${ }^{10}$

1. Reinstatement

2. New for Old.

3. Agreed Additional Cost..

4. Valued Policy. ${ }^{8}$

Konsekuensi indemnity sebagaiberikut :

1. Adanya hak indemnity harus dibuktikan bahwa tertanggung menderita kerugian yang dapat diukurkan uang;

2. Indemnity diukur oleh kerugian yang

8 Abdul Kadir Muhammad. 1978. Pokok-pokok Hukum Pertanggungan. Bandung: Alumni, hlm. 100. diterita oleh tertanggung sesaat sebelum terjadi kerugian;

3. Sum Insured adalah maksimum jumlah penggantian kerugian;

4. Tertanggung akan diganti kerugiannya hanya sebesar kerugian yang diderita;

5. Tidak ada loss maka tidak ada indemnity walaupun ada kecelakaan;

6. Apabila ada hak-hak lain yg timbul karenanya maka hak tersebut harus diberikan kepada penanggung yg telah membayar kerugian; dan

7. Tertanggung tidak boleh mendapatkan ganti rugi lebih atas setiap terjadi kerugian dan tidak boleh mendapatkan penggantian dari beberapa penanggung bila telah full indemnity.

Dalam hal penentuan besarnya uang pertanggungan juga berkaitan dengan jumlah objek yang diasuransikan. Jumlah yang diasuransikan adalah jumlah yang dipakai sebagai ukuran untuk menentukan jumlah maksimum ganti kerugian. Jumlah wajib dibayar oleh penanggung dalam klaim asuransi kerugian. Jumlah yang diasuransikan erat sekali hubungannya dengan nilai benda objek asuransi. Dengan ditentukan jumlah yang diasuransikan, dapat diketahui apakah asuransi itu di bawah nilai benda objek asuransi atau melebihi nilai benda asuransi. Dengan demikian dapat ditentukan jumlah maksimum ganti kerugian yang dapat dibayar, jika timbul kerugian akibat peristiwa yang menjadi beban penanggung.

Menurut Pasal 253 ayat (1) KUHD, bahwa asuransi yang melebihi jumlah nilai benda atau kepentingan yang sesungguhnya hanya sah sampai jumlah nilai benda tersebut. Apabila jumlah yang diasuransikan lebih besar daripada nilai benda sesungguhnya, penanggung hanya bertanggungjawab membayar 
klaim ganti kerugian sampai jumlah nilai benda sesungguhnya dalam hal timbul kerugian total.

Selanjutnya menurut Pasal 253 ayat (2) KUHD, bahwa apabila suatu benda tidak diasuransikan dengan nilai penuh, maka jika timbul kerugian, penanggung hanya diwajibkan memenuhi klaim ganti kerugian menurut perbandingan antara bagian yang diasuransikan dan bagian yang tidak diasuransikan. Ketentuan ini masih bisa disimpangi para pihak, asalkan diperjanjikan dengan tegas dalam polis tanpa memperhatikan asas keseimbangan (indemnitas), kerugian yang menimpa benda asuransi itu akan diganti sepenuhnya sampai jumlah yang diasuransikan yang diatur dalam Pasal 253 ayat (3) KUHD.

Dalam hal pergantian biaya pertanggungan terhadap kerugian pada asuransi anggota tubuh manusia juga harus memperhatikan nilai benda objek asuransi, karena nilai benda objek asuransi dapat berubah-ubah dari waktu ke waktu bergantung pada sifat dan keadaan benda objek tersebut. Jika benda objek asuransi adalah benda tetap seperti rumah, misalnya tidak akan mengalami banyak perubahan bahkan mungkin tetap atau meningkat harganya. Benda objek asuransi yang mudah susut, rusak atau busuk akan mengalami perubahan nilai atau penyusutan, sehingga nilai pada waktu diasuransikan menjadi berbeda dengan nilai pada waktu terjadi peristiwa yang menimbukan kerugian. Untuk benda objek asuransi berupa anggota tubuh manusia juga akan mengalami perubahan seiring dengan waktu berjalan, sehingga perusahaan asuransi dalam hal ini penanggung harus memperhatikan jangka waktu pertanggungan tersebut. Jika berpedoman pada tujuan asuransi yaitu untuk memberikan ganti kerugian yang sungguh-sungguh dialami oleh tertang- gung, maka wajarlah apabila nilai benda objek asuransi yang dijadikan dasar perhitungan adalah nilai benda objek asuransi pada waktu terjadi peristiwa yang menimbulkan kerugian itu.

Asas indemnitas dapat digariskan atau ditarik kepada dua ketentuan pokok, yaitu:

1. Bahwa tertanggung (atau orang ketiga untuk kepentingan siapa diadakan asuransi itu) harus mempunyai kepentingan atas peristiwa tidak tertentu itu dengan pengertian bahwa sebagai akibat dari peristiwa itu ia menderita kerugian (Pasal 250 jo 268 KUHD). Apabila kepentingan dalam arti seperti itu tidak ada dalam perjanjian tersebut tidak mungkin dimaksudkan untuk mengganti kerugian dan sebagaimana dikatakan di atas bahwa justru salah satu sifat asasi atau sifat inti dari perjanjian asuransi itu adalah sebagai perjanjian untuk mengganti rugi, ganti rugi mana harus seimbang dengan kerugian yang sungguh-sungguh diderita dan dipertimbangkan dengan jumlah yang diasuransikan. Adakalanya suatu ganti rugi itu tidaklah seluruh kerugian yang diderita.Ini dapat terjadi apabila tidak seluruhnya harga objek asuransi itu diasuransikan, sehingga masih ada risiko yang ditanggung oleh tertanggung sendiri; dan

2. Bahwa asuransi itu tidak boleh menjurus pada pemberian ganti rugi yang lebih besar daripada kerugian yang diderita (253 KUHD).

Pelaksanaan yang amat penting dari ketentuan pokok yang kedua ini terdapat dalam beberapa ketentuan bahwa:

a. Penggantian kerugian maksimal atas mana penanggung mengikat dirinya (yaitu jumlah yang dipertanggungkan verzekerdesom) tidak boleh melebihi dari nilai 
benda asuransi. Apabila jumlah yang diasuransikan itu ternyata melebihi, maka di sinilah dapatdijumpai asuransi di atas nilai benda dan persoalan ini harus diselesaikan menurut Pasal 253 Ayat (1) KUHD yang menentukan bahwa: Oververzekering hanya untuk sejumlah harga benda yang diasuransikan.

b. Melarang diadakannya asuransi yang kedua untuk waktu sama dan terhadap bahaya yang sama atas benda-benda yang sudah diasuransikan untuk hargapenuh dengan ancaman batal. Ini tegas diatur dalam Pasal 252 KUHD.Andaikata asuransi seperti itu tidak dilarang, maka mungkin seseorang akan menerima ganti rugi dua kali yang melebihi kerugian yang diderita.

3. Bahwa asuransi itu adalah suatu perjanjian bersyarat artinya bahwa kewajiban mengganti rugi dari penanggung hanya dilaksanakan kalau peristiwa yang tertentu atas mana diadakan asuransi itu terjadi. Jadi, pelaksanaan kewajiban mengganti rugi digantungkan pada satu syarat.

4. Asuransi adalah suatu perjanjian timbalbalik, artinya bahwa kewajiban penanggung mengganti rugi dihadapkan dengan kewajiban tertanggung membayar premi, walaupun dengan pengertian bahwa kewajiban membayar premi itu tidak bersyarat atau tidak digantungkan pada satu syarat.

Dihubungkan dengan asuransi anggota tubuh manusia, maka nilai benda sebagai objek yang dipertanggungkan, maka tidak dapat diterapkan atau terdapat kesulitan dalam menerapkan asas indemnitas.

\section{PENUTUP}

Dalam hukum yang berlaku di Indonesia khususnya peraturan perundang-undangan mengenai asuransi belum mengatur secara eksplisit mengenai perjanjian asuransi anggota tubuh manusia, namun demikian dewasa ini perjanjian asuransi anggota tubuh manusia telah dilakukan, sehingga masih menggunakan ketentuan yang berlaku di dalam KUH Perdata, KUHD, UU No. 40/2014. Hal yang diperjanjikan yaitu anggota tubuh manusia mengacu kepada makna asuransi yang terkandung dalam ketentuan Pasal 1 angka 1 UU No. 40/2014, yaitu salah satunya adalah raga yang dalam hal ini bisa diartikan sebagai anggota tubuh manusia.

Asuransi anggota tubuh manusia termasuk ke dalam kategori asuransi sejumlah uang. Mengenai penentuan besarnya uang pertanggungan (sum insured) dan besarnya ganti kerugian asuransi anggota tubuh manusia apabila dihubungkan dengan asas indemnitas, maka tidak dapat diterapkan atau terdapat kesulitan dalam menerapkan asas indemnitas dalam asuransi anggota tubuh manusia.

Dalam rangka kepastian hukum kiranya perlu diatur tersendiri mengenai peraturan perundang-undangan mengenai asuransi anggota tubuh manusia, seperti beberapa asuransi benda lainnya, seperti motor, perumahan yang telah diatur secara tersendiri dalam berbagai peraturan perundang-undangan.

\section{BIBLIOGRAFI}

Subekti, R dan R. Tjitrosudibio. 1976. Kitab Undang-Undang Hukum Dagang. Jakarta: Pradnya Paramitha.

Muhammad, Abdul Kadir. 1978. Pokok-pokok Hukum Pertanggungan. Bandung: Alumni.

Salim, Abbas. 2007. Asuransi dan Manajemen Risiko. Jakarta: RajaGrafindo Persada.

Junaedy. Ganie A. 2011. Hukum Asuransi Indonesia. Jakarta: Sinar Grafika. 
Muhammad, Abdukadir. 2011. Hukum Asuransi Indonesia. Bandung: Citra Aditya Bakti.

Rastuti, Tuti. 2011. Aspek Hukum Perjanjian Asuransi. Yogyakarta: Buku Seru.

Anonim. 2013. Asuransi Tubuh Ala Selebriti. Diakses melalui http://brighterlife. co.id/2013/09/27/asuransitubuhalaseleb riti/\#sthash.TPD7iYxN.dpuf. [Akses 15 Maret 2016].

Anonim. 2015. Bagian-bagian Tubuh Manusia Dan Fungsinya. Diakses melalui http://usaha321.net/bagian-bagian-tubuh-manusia-dan-fungsinya.html. [Diakses 20 Maret 2017].

Ariyanti, Fikri. 2015. Artis Hingga Pesebakbbola RI Asuransikan Tubuhnya. Diaksesmelalui http://askrida.com/artishinggapesepakbolariasuransikantubuhnya. html\#.Vy9c6CHnE28. [diakses 15 Maret 2016].

Budi, Afrianto. 2012. Prinsip Indemnity, diakses melalui http://www.akademiasuransi.org/2012/09/prinsip-indemnity.html. [Diakses 6 Desember 2016].

Sembiring, Sentosa. 2014. Hukum Asuransi. Bandung: Nuansa Aulia.

\section{Peraturan Perundang-undang}

Kitab Undang-Undang Hukum Dagang Staatsblad Tahun 1847 Nomor 23.

Kitab Undang-Undang Hukum Perdata Staatsblad Tahun 1847 Nomor 23.

Undang-Undang Nomor 40 Tahun 2014 tentang Perasuransian Lembaran Negara Republik Indonesia Tahun 2014 Nomor 337, Tambahan Lembaran Negara Republik Indonesia Nomor 5618. 